\title{
Effect of replacing maize fodder with maize silage on feed intake, digestibility and milk yield of early-lactation Nili Ravi buffaloes
}

\author{
Rafiuddin ${ }^{1,2^{*}}$, Jalees Ahmed Bhatti ${ }^{1}$, Muhammad Qamer Shahid ${ }^{1}$, \\ Muhammad Saadullah ${ }^{1}$, Hamid Mustafa ${ }^{1}$, Mehtab Ahmad ${ }^{2}$, \\ Muhammad Akbar Nasar ${ }^{2}$, Rehmanullah Khan ${ }^{3}$ and Asghar Khan ${ }^{2}$ \\ 1. Department of Livestock Production, Ravi Campus, University of Veterinary \& Animal Sciences, Lahore- \\ Pakistan \\ 2. Department of Livestock and Dairy Development Spinny Road Quetta-Pakistan \\ 3. Department of Dairy Technology, Ravi Campus, University of Veterinary \& Animal Sciences, Lahore- \\ Pakistan \\ *Corresponding author's email: rafi_kaka27@yahoo.com \\ Citation
}

Rafiuddin, Jalees Ahmed Bhatti, Muhammad Qamer Shahid, Muhammad Saadullah, Hamid Mustafa, Mehtab Ahmad, Muhammad Akbar Nasar, Rehmanullah Khan and Asghar Khan. Effect of replacing maize fodder with maize silage on feed intake, digestibility and milk yield of early-lactation Nili Ravi buffaloes. Pure and Applied Biology. Vol. 7, Issue 4, pp1171-1176. http://dx.doi.org/10.19045/bspab.2018.700136

\begin{tabular}{llll}
\hline Received: $13 / 07 / 2018$ & Revised: 27/08/2018 & Accepted: 29/08/2018 & Online First: 30/08/2018 \\
\hline
\end{tabular}

\section{Abstract}

The objective of current study was to assess the effect of replacing maize fodder with maize silage on productive performance of early-lactation buffaloes. Sixteen primiparous Nili Ravi buffaloes in early lactation ( $40 \pm 10$ days in milk), with similar milk yield were randomly divided into 4 treatment groups (4 animals /group). Feed was offered ad libitum as a total mixed ration (TMR) with forage to concentrate ratio of 60 to $40 \%$ on dry matter basis. The dietary treatments included control (MFA; maize fodder $60 \%$ of TMR), MS20 (20\% maize silage $+40 \%$ maize fodder), MS40 (40\% maize silage $+20 \%$ maize fodder), and MSA (maize silage $60 \%$ of TMR). Treatments continued for 90 days. The results revealed that highest dry matter intake was recorded in MFA $(17.99 \pm 0.06 \mathrm{~kg} / \mathrm{d}$; mean \pm SE) and lowest in MSA $(16.22 \pm 0.07)$. Similar pattern was observed for crude protein, neutral detergent fiber and acid detergent fiber intakes. Dry matter digestibility was highest in MFA (64.49 $\pm 0.54 \%)$ and lowest in MSA (60.17 $\pm 0.75)$. Daily milk yield was significantly $(P<0.05)$ higher in MFA $(8.97 \pm 0.12)$ followed by MS20 $(8.61 \pm 0.09)$, MS40 $(8.45 \pm 0.10)$, and MSA $(8.31 \pm 0.07)$. The MFA and MS20 groups had lower fat $(6.76 \pm 0.10$ and $6.76 \pm 0.11 \%)$ compared to MS40 and MSA $(7.18 \pm 0.14$ and $7.17 \pm 0.12 \%)$. In conclusion, the buffaloes fed on TMR with lower silage levels performed better than buffaloes on higher silage levels.

Keywords: Buffaloes; Digestibility; Maize silage; Milk yield

\section{Introduction}

Buffalo (Bubalus bubalis) is the major dairy animal in Pakistan, contributing about $67 \%$ of total milk production in the country [1]. Most of the buffaloes are raised in rural areas in small herds ( $<3$ animals) and are fed seasonal fodders or cereal crop leftovers. In peri urban areas, the dairy buffalo is kept for commercial purposes and raised on wheat straw based TMR along with small quantity of fresh fodder. The seasonal fodder production poses a challenge for dairy farmers to feed their animals when fodder supply is limited 
especially during summer (May-July) and winter (November - January) months [2]. Silage is a viable solution to ensure fodder supply during lean periods [3].

Despite benefits of silages, it has been reported that the DM intake was lower in silage fed dairy cows due to the fermentation products causing lower $\mathrm{pH}$ in silages [4]. Also, DM content of silages might also affect the DM intake in dairy cattle [5]. In dairy buffaloes, the silage feeding has not been extensively researched [6]. Under such scenario, a study was needed to explore the effect of fodder replacement with silage in lactating dairy buffaloes.

The objective of present study was to investigate the effect of maize fodder replacement with maize silage on productive performance in lactating dairy buffaloes.

\section{Materials and methods}

\section{Experimental animals and housing}

The experiment was carried out at Buffalo Research Institute, Pattoki, District Kasur, Pakistan. The experiment was started on October 20, 2013 and ended on January 20, 2014. Sixteen primiparous Nili Ravi buffaloes in early lactation ( $40 \pm 10$ days in milk) having similar milk yield were selected from the herd. The buffaloes were kept in naturally ventilated shed and were individually tied. The partitions were made at manger to record individual feed intake and rubber tubs were provided for free access of water. Before the start of the experiment, all animals were vaccinated and dewormed according to the farm protocol.

\section{Treatment diets}

The selected buffaloes were randomly divided into 4 treatment groups with 4 animals in each group. The feed was offered ad libitum as a TMR with forage to concentrate ratio of 60 to $40 \%$ on dry matter basis. The dietary treatments included control (MFA; maize fodder $60 \%$ of TMR), MS20 (20\% maize silage and $40 \%$ maize fodder), MS40 (40\% maize silage and 20\% maize fodder), and MSA (maize silage, $60 \%$ of TMR). The treatment diets were offered for 90 days. The experimental diets differed in roughage source with varying level of silage whereas concentrate was similar for all TMRs. The chemical composition of all 4 diets is presented in (Table 1).

\section{Feed intake, milk production and milk composition}

The TMR was prepared daily and measured quantity was offered twice a day (morning and evening) at ad libitum (10\% feed refusal) to each animal. The feed refused was collected every morning before offering fresh feed. Dry matter intake and milk yield were recorded daily, milk samples were collected weekly and analyzed for fat, protein and lactose by milk analyzer (Lactoscan-S, Milkotronic Ltd., Bulgaria).

The intake of DM, CP, NDF and ADF for each animal was recorded daily, whereas, body weights of all animals was taken monthly. Milk yield was recorded daily (morning and evening).

\section{Digestibility trial}

Three days digestibility trial was carried out in the last week of experiment as described by [7]. One animal from each group was randomly selected for the trial. Fecal grab samples were collected for every $3 \mathrm{~h}$ interval during $24 \mathrm{~h}$ with a total of 8 samples daily [8]. For each collection, $50 \mathrm{~g}$ of sample was weighed and composited to form one sample per animal.

\section{Sample preparation and chemical analysis}

Feed, orts and fecal samples were dried in the oven at $60^{\circ} \mathrm{C}$ for $72 \mathrm{~h}$ and analyzed for $\mathrm{DM} \%$, percent digestibility and proximate analysis. The samples were analyzed for $\mathrm{CP}$ [9], NDF, and ADF [10] at Animal Nutrition Laboratory, Ravi campus, UVAS. The gross energy of the feed samples was determined by IKA C-2000 Bomb Calorimeter, while metabolizable energy (ME) was calculated as $63 \%$ of the gross energy [11]. 
Table 1. Ingredients and chemical composition of four experimental diets

\begin{tabular}{|c|c|c|c|c|}
\hline & \multicolumn{5}{|c|}{ Experimental diets $^{\mathbf{1}}$} \\
\hline Ingredients (\% of DM) & MFA & MS20 & MS40 & MSA \\
\hline Maize fodder & 60.00 & 40.00 & 20.00 & ----- \\
\hline Maize silage & ------ & 20.00 & 40.00 & 60.00 \\
\hline Cotton seed cake & 04.00 & 04.00 & 04.00 & 04.00 \\
\hline Canola meal & 10.00 & 10.00 & 10.00 & 10.00 \\
\hline Soybean meal & 15.00 & 15.00 & 15.00 & 15.00 \\
\hline Maize grain & 3.00 & 3.00 & 3.00 & 3.00 \\
\hline Rice polishing & 5.00 & 5.00 & 5.00 & 5.00 \\
\hline Molasses & 2.00 & 2.00 & 2.00 & 2.00 \\
\hline Minerals Mixture & 1.00 & 1.00 & 1.00 & 1.00 \\
\hline Total (\%) & 100 & 100 & 100 & 100 \\
\hline DM (\%) & 25.6 & 28.5 & 32.0 & 35.6 \\
\hline Crude protein & Chemical composition (\% of DM) & \\
\hline Neutral detergent fiber & 16.93 & 16.69 & 16.45 & 16.21 \\
\hline Acid detergent fiber & 38.70 & 39.10 & 40.35 & 41.70 \\
\hline Gross energy (cal/g) & 22.78 & 23.06 & 24.02 & 25.47 \\
\hline
\end{tabular}

${ }^{1}$ Four experimental diets (60:40 forage: concentrate ratio; DM basis) i.e. MFA (maize fodder 60\% of TMR), MS20 (20\% maize silage and $40 \%$ maize fodder), MS40 (40\% maize silage and 20\% maize fodder), and MSA (maize silage $60 \%$ of TMR)

\section{Statistical analysis}

The collected data were analyzed by oneway ANOVA technique under completely randomized design using SAS (SAS 9.1.3 Portable; SAS Institute Inc., Cary, NC). Differences between treatment means were tested through Duncan's multiple range test.

\section{Results}

\section{Feed intake, milk production and milk composition}

Dry matter intake significantly decreased with increasing level of maize silage in TMR ( $P<0.05$; Table 2). The highest DMI was recorded in MFA $(17.99 \pm 0.06 \mathrm{~kg} / \mathrm{d})$ followed by MS20 (17.81 \pm 0.06$)$, MS40 (17.68 \pm 0.06$)$ and MSA (16.22 \pm 0.07$)$. A similar trend was observed for $\mathrm{CP}$, NDF and ADF intake (Table 2).

The increasing level of silage in TMR negatively affected milk yield in dairy buffaloes (Table 2). The average milk yield was significantly $(P<0.05)$ higher in MFA $(8.97 \pm 0.12 \mathrm{~kg} / \mathrm{d})$ followed by MS20 (8.61 \pm 0.09$)$, MS40 (8.45 \pm 0.10$)$ and MSA (8.31 \pm 0.07 ; Table 2$)$. The milk composition showed contrary trends as that of milk yield (Table 2). Milk fat \% increased with increasing silage inclusion in TMR. Milk fat was higher in MS40 and MSA (7.18 \pm 0.14 and $7.17 \pm 0.12)$ treatment groups, and lower in MFA and MS20 groups $(6.76 \pm 0.10$ and $6.76 \pm 0.11)$, respectively (Table 2 ). Similarly, solid not fat (SNF), protein, and lactose were also significantly $(P<0.05)$ higher in silage based TMR groups as compared to fresh fodder group (Table 2).

\section{Digestibility}

Dry matter digestibility decreased with increasing level of silage in TMR (Table 2). Dry matter digestibility was significantly $(P<0.05)$ higher in buffaloes fed MFA diet $(64.49 \pm 0.54 \%)$ followed by MS20 (62.07 \pm 0.20$), \quad M S 40 \quad(60.81 \pm 0.45)$ and MSA (60.17 \pm 0.75 ; Table 2). The CP digestibility was significantly $(P<0.05)$ higher in MFA diet $(72.90 \pm 0.32 \%)$ compared to all others (Table 2). All the three silage-based diets had similar $\mathrm{CP}$ digestibility (Table 2). Similarly, highest NDF digestibility $(53.07 \pm 0.50 \%)$ was observed in MFA group followed by MS20 (51.78 \pm 0.29$), \quad$ MS40 (50.93 \pm 0.34$)$ and MSA (50.67 \pm 0.18 ; Table 2). 
Table 2. Performance of Nili Ravi buffaloes fed different levels of Maize silage

\begin{tabular}{|c|c|c|c|c|}
\hline & \multicolumn{5}{|c|}{ Experimental diets $^{1}$} \\
\hline MFA & MS20 & MS40 & MSA \\
\hline Item & $17.99 \pm 0.06^{\mathrm{a}}$ & $17.81 \pm 0.06^{\mathrm{b}}$ & $17.68 \pm 0.06^{\mathrm{b}}$ & $16.22 \pm 0.07^{\mathrm{c}}$ \\
\hline CP, kg/d & $3.23 \pm 0.01^{\mathrm{a}}$ & $3.19 \pm 0.02^{\mathrm{b}}$ & $3.15 \pm 0.01^{\mathrm{c}}$ & $2.86 \pm 0.01^{\mathrm{d}}$ \\
\hline NDF, kg/d & $9.48 \pm 0.06^{\mathrm{a}}$ & $9.44 \pm 0.04^{\mathrm{a}}$ & $9.23 \pm 0.08^{\mathrm{b}}$ & $8.75 \pm 0.04^{\mathrm{c}}$ \\
\hline ADF, kg/d & $4.58 \pm 0.01^{\mathrm{a}}$ & $4.51 \pm 0.02^{\mathrm{b}}$ & $4.35 \pm 0.02^{\mathrm{c}}$ & $4.27 \pm 0.02^{\mathrm{d}}$ \\
\hline Milk yield, kg/d & $8.97 \pm 0.12^{\mathrm{a}}$ & $8.61 \pm 0.09^{\mathrm{b}}$ & $8.45 \pm 0.10^{\mathrm{bc}}$ & $8.31 \pm 0.07^{\mathrm{c}}$ \\
\hline \multicolumn{5}{|c|}{ Milk composition\% $^{\mathrm{b}}$} \\
\hline Fat & $6.76 \pm 0.10^{\mathrm{b}}$ & $6.76 \pm 0.11^{\mathrm{b}}$ & $7.18 \pm 0.14^{\mathrm{a}}$ & $7.17 \pm 0.12^{\mathrm{a}}$ \\
\hline SNF & $10.15 \pm 0.05^{\mathrm{b}}$ & $10.32 \pm 0.07^{\mathrm{a}}$ & $10.37 \pm 0.05^{\mathrm{a}}$ & $10.35 \pm 0.05^{\mathrm{a}}$ \\
\hline Protein & $3.94 \pm 0.02^{\mathrm{b}}$ & $4.05 \pm 0.03^{\mathrm{a}}$ & $4.06 \pm 0.02^{\mathrm{a}}$ & $4.06 \pm 0.03^{\mathrm{a}}$ \\
\hline Lactose & $5.31 \pm 0.03^{\mathrm{b}}$ & $5.45 \pm 0.04^{\mathrm{a}}$ & $5.47 \pm 0.02^{\mathrm{a}}$ & $5.44 \pm 0.03^{\mathrm{a}}$ \\
\hline Ash & $0.83 \pm 0.003^{\mathrm{b}}$ & $0.84 \pm 0.006^{\mathrm{a}}$ & $0.84 \pm 0.003^{\mathrm{a}}$ & $0.84 \pm 0.004^{\mathrm{a}}$ \\
\hline Digestibility\% & \multicolumn{3}{c|}{} \\
\hline DM & $64.49 \pm 0.54^{\mathrm{a}}$ & $62.07 \pm 0.20^{\mathrm{b}}$ & $60.81 \pm 0.45 \mathrm{~b}^{\mathrm{c}}$ & $60.17 \pm 0.75^{\mathrm{d}}$ \\
\hline CP & $72.90 \pm 0.32^{\mathrm{a}}$ & $70.89 \pm 0.28^{\mathrm{b}}$ & $70.70 \pm 0.27^{\mathrm{b}}$ & $70.11 \pm 0.27^{\mathrm{b}}$ \\
\hline NDF & $53.07 \pm 0.50^{\mathrm{a}}$ & $51.78 \pm 0.29^{\mathrm{b}}$ & $50.93 \pm 0.34^{\mathrm{bc}}$ & $50.67 \pm 0.18^{\mathrm{c}}$ \\
\hline
\end{tabular}

a,b,c Values with different superscripts within a row are statistically different $(P<0.05)$.

${ }^{1}$ Four experimental diets (60:40 forage: concentrate ratio; DM basis) i.e. MFA (maize fodder $60 \%$ of TMR), MS20 (20\% maize silage and $40 \%$ maize fodder), MS40 (40\% maize silage and 20\% maize fodder), and MSA (maize silage $60 \%$ of TMR)

\section{Discussion}

\section{Feed intake, milk production and milk composition}

The current findings of decreased DM intake for silage fed buffaloes were in line with previous studies conducted on buffaloes. The study on buffaloes [6] reported a decrease in DM intake in berseem silage fed lactating buffaloes. They attributed the decrease in DM intake to the presence of fermentation products in silage. Similarly, the replacement of Jambo grass (Sorghum bicolour Sorghum sudanefe) with Jambo grass silage in Nili Ravi buffaloes decreased DM intake of silage fed animals [12]. Likewise, a study [4] explained that low $\mathrm{pH}$ due to the fermentation products in silages might cause the decrease in DM intake. The replacement of maize fodder with maize silage had the same effect on DM intake as that of other silage crops. Decreased CP intake with increasing silage ratio was in accordance to what has been reported previously $[6,12]$. The degradation of $\mathrm{CP}$ to non-protein nitrogen during ensiling process could explain the decreased $\mathrm{CP}$ intake in silage fed animals [4]. The higher
NDF and ADF intake in high fodder groups (MFA and MS20) in present study was similar to previous findings $[6,12,13]$. The lower DM intake in silage-based groups might also have lowered the NDF intake. Decreased ruminal $\mathrm{pH}$ in silage fed diets might also have affected the degradation of NDF due to higher lactic acid contents and thus reduced NDF intake.

Higher milk yield in high fodder compared to high silage-based diet was in line to [6] who reported higher milk yield in berseem fodder compared to berseem silage diets. Likewise, a higher milk yield was reported in sorghum grass than sorghum silage [12]. Higher milk yield could be due to higher DM intake in fodder-based diets. Increased milk fat \% in our study was similar to [12] who found higher milk fat in silage-based diets. The acetate is a major end product of lactate fermentation, the conversion of lactic acid content of silage-based diets to acetate might have improved the milk fat contents [14]. Increased protein content in current study was similar to [15] who found increase in milk protein concentration in silage fed diets and attributed that to efficient microbial protein synthesis. 


\section{Digestibility}

The current results of lower DM, CP, and NDF digestibility in silage-based TMR were in line with previous studies $[6,12]$. The higher digestibility in fodder-based diets could be due to higher concentration of soluble carbohydrates and lower lignin content in the fodder than that of its silage [16]. Also, low $\mathrm{pH}$ of silage due to lactic acid contents, decreased the ruminal $\mathrm{pH}$ and thus reduced hemicellulose and cellulose digestibility by depressing the growth of cellulolytic bacteria in the rumen of silage fed animal [6].

The DM, CP, NDF digestibility values were also in range as reported previously. A study [6] reported digestibility of DM as 64.8 and $62 \%$ and $\mathrm{CP}$ as 72 and $71.5 \%$ for berseem fodder and berseem silage, respectively. Similarly, about 71.3 and $71.1 \%$ CP digestibility was reported for oat fodder and oat silage, respectively [13]. Likewise, a study [12] reported 71.3 and $71.13 \%$ CP digestibility for jumbo grass and jumbo silage respectively. However, the current findings showed slightly higher DM digestibility than that of previous studies $[12,13]$. The different fodders in their diets could explain that difference. However, it was evident from these findings that $\mathrm{CP}$ digestibility was more consistent than DM and NDF digestibility in buffaloes irrespective of fodder types.

\section{Conclusion}

The results of present study revealed that higher levels of silage in TMR negatively impacted DM intake and milk yield in buffaloes. However, increasing silage in buffalo diet increased fat and SNF content. The maize fodder can be replaced with maize silage in buffaloes for comparable performance.

\section{Authors' contributions}

Conceived and designed the experiments: Rafiuddin \& JA Bhatti, Performed the experiments: Rafiuddin, Analyzed the data: MQ Shahid, M Ahmed \& H Mustafa, Contributed materials/ analysis/ tools: MA Nasar, R Khan \& A Khan, Wrote the paper: Rafiuddin, MQ Shahid \& M Saadullah.

\section{Acknowledgments}

The authors are obliged to Higher Education Commission of Pakistan for providing financial assistance to conduct this study. The authors also acknowledge the farm staff at Buffalo Research Institute, for their assistance in conducting the feeding trial.

\section{References}

1. Afzal M, Anwar M \& Mirza MA (2007). Some factors affecting milk yield and lactation length in Nili-Ravi buffaloes. Pak Vet J 27(3): 113-117.

2. Rasool S, Ahmad G \& Abdullah M (1996). Fodder conservation, crop residues and by products in livestock production system. Proceedings of the National Conference on "Improvement, Production and Utilization of Fodder Crops in Pakistan." Organized by FAO/PARC 176-186.

3. Khan SH, Azim A, Sarwar M, \& Khan AG (2011). Effect of maturity on comparative nutritive value and Fermentation characteristics of maize, sorghum and millet silages. Pak J Bot 43(6): 2967-2970.

4. Ruiz TM, Sanchez WK, Straples CR \& Sollenberger LE (1992). Comparison of "Mott" dwarf elephant grass silage and corn silage for lactating dairy cows. J Dairy Sci 75(2): 533-540.

5. Yahaya MS, Goto M, Yimiti W, Smerjai B \& Kawamoto Y (2004). Additives effects of fermented juice of epiphytic lactic acid bacteria and acetic acid on silo fermentation and ruminal degradability of tropical elephant grass. J Anim Vet Adv 3(2): 115-121.

6. Sarwar M, Khan MA, Nisa M \& Touqir NA (2005). Influence of berseem and Lucerne silages on feed intake, nutrient digestibility and milk yield in lactating Nili buffaloes. AsianAustralas J Anim Sci 18(4): 475-478.

7. Khan MA, Sarwar M, Nisa M \& Khan MS (2004). Feeding value of urea treated corncobs ensiled with or without enzose (corn dextrose) for 
lactating crossbred cows. AsianAustralas J Anim Sci 17(8):1093-1097.

8. Sarwar M, Firkins JL \& Estridge ML (1991). Effect of replacing neutral detergent fiber of forage with soy hulls and corn gluten feed for dairy heifers. J Dairy Sci 74(3):1006-1015.

9. AOAC (1990). Official Methods of Analysis. $15^{\text {th }}$ ed. Association of Official Analytical Chemists, Arlington, Virginia, USA.

10. Van-Soest PJ, Robertson HB \& Lewis BA (1991). Method of dietary fiber, neutral detergent fiber and non-starch polysaccharides determination in relation to animal material. J Dairy Sci 74(10): 3583-3597.

11. Mandal AB, Paual SS \& Pathak NN (2003). Nutrient requirements and feeding of buffaloes and cattle. Published by Int. Book Distributing Co. Charbagh, Lucknow, India. P-23.

12. Tauqir NA, Sarwar M, Jabbar MA \& Mahmood S (2009). Nutritive value of jumbo grass (sorghum bicolour sorghum sudanefe) silage in lactating
Nili-Ravi buffaloes. Pak Vet J 29(1): 510.

13. Khan MA, Sarwar M, Nisa M, Iqbal Z, Khan MS, Lee WS, Lee HJ \& Kim HS (2006). Chemical composition, in situ digestion kinetics and feeding value of oat grass (avena sativa) ensiled with molasses for Nili-Ravi Buffaloes. Asian-Australas J Anim Sci 19(8): 1127-1133.

14. Chamberlain DG \& Robertson S (1992). The effects of the addition of various enzyme mixtures on the fermentation of perennial rye grass silage and on its nutritional value for milk production in dairy cows. Anim Feed Sci Technol 37(3-4): 257-264.

15. Givens DI \& Rulquin H (2004). Utilization by ruminants of nitrogen compounds in silage-based diets. Anim Feed Sci Technol 114(1-4): 1-18.

16. Khorasani GR, Jedel PE, Helm JH \& Kennelly JJ (1997). Influence of stage of maturity on yield components and chemical composition of cereal grain silages. Can J Anim Sci 77(2): 259267. 